\section{soment HORIZON}

PENDIDIKAN
JURNAL HORIZON PENDIDIKAN

Publish by: Library of STKIP PGRI Sumatera Barat

E-ISSN : 2775-5770

Vol. 1 No. 4 (November 2021) (676-687)

http://ejournal.stkip-pgri-sumbar.ac.id/index.php/horizon

\title{
PERANCANGAN SISTEM INFORMASI PENJUALAN MOTOR BEKAS BERBASIS WEB PADA ZIDAN JAYA MOTOR
}

\author{
Rila Kurniawan, Heri Mulyono, Irsyadunas \\ Program Studi Pendidikan Informatika STKIP PGRI Sumatera Barat \\ rilakurniawan6484@gmail.com
}

Submitted: 15-10-2021, Reviewed: 03-11-2021, Accepted: 09-11-2021

\begin{abstract}
Zidan Jaya Motor is a company that serves the sale and purchase of used motorcycles, from various brands and types of motorcycles. The problem that is often encountered is the ineffectiveness of sales services in terms of time and effort because they still use manual data collection in the company's parent book. The purpose of this research is to design a web-based used motorcycle sales application. This sales information system planning uses the SDLC (system development life cycle) development method with the PHP (hypertext markup language) programming language. This sales application makes it easy for Zidan Jaya Motor to manage goods data, sales reports, optimize services and maintain company data security. With the support of human resources and computerized information systems.
\end{abstract}

Keywords : System, Information, Sales, Zidan Jaya Motor.

\section{PENDAHULUAN}

Kemajuan usaha perdagangan yang sangat pesat pada saat ini menjadikan informasi sebagai hal yang sangat penting peranannya dalam menunjang jalannya pengoperasian sistem informasi demi tercapainya tujuan yang diinginkan pemilik usaha. Teknologi internet sudah terbukti merupakan salah satu media informasi yang efektif dalam penyebaran informasi yang dapat diakses oleh siapa saja, kapan saja dan dimana saja. Hanya dari rumah atau ruang kantor, calon pembeli dapat melihat produk pada layar komputer, mengakses informasinya, memesan dan membayar dengan pilihan yang tersedia. Transaksi penjualan secara online mempunyai calon pembeli yang potensial dari seluruh dunia (Iriadi \& Rosdiana, 2017). 


\section{JURNAL \\ HORIZON}

PENDIDIKAN

JURNAL HORIZON PENDIDIKAN

Publish by: Library of STKIP PGRI Sumatera Barat

E-ISSN : 2775-5770

Vol. 1 No. 4 (November 2021) (676-687)

http://ejournal.stkip-pgri-sumbar.ac.id/index.php/horizon

Dipimpin oleh Bapak Dahrul selaku pemilik usaha, Zidan Jaya Motor berdiri pada tahun 2014 yang berlokasi di Petok, Kabupaten Pasaman, Sumatera Barat. Dealer ini merupakan perusahaan yang melayani jual beli motor bekas berbagai merek dan tipe motor, sistem penjualan yang digunakan belum memanfaatkan teknologi komputerisasi, setiap sepeda motor yang datang dan terjual hanya melalui tahap pencatatan secara manual dalam buku induk perusahaan. Kendala yang sering ditemukan adalah kurang efektifnya pelayanan penjualan dari segi waktu dan tenaga yang dibutuhkan, oleh karena itu, dirancang sebuah aplikasi penjualan berbasis web, yang dapat melakukan penjualan secara online dengan tujuan meningkatkan pelayanan penjualan, membantu dalam proses pengolahan data dan laporan penjualan dengan akurat dan cepat.

\section{METODE PENELTIAN}

Perencanaan sistem informasi penjualan ini menggunakan metode pengembangan SDLC (System
Development Life Cycle) waterfall model. Dengan alat bantu perancangan UML (Unifield Modelling Language)

Menurut pendapat Rossa A. S (2018) mengemukakan bahwa SDLC merupakan proses pengembangan atau perubahan suatu sistem perangkat lunak dengan menggunakan model-model dan metodologi yang dipakai pengguna (user) dalam mengembangkan sistem perangkat lunak sebelumnya berdasarkan best practice atau tahapan yang telah teruji dengan baik.

UML merupakan bahasa visual untuk pemodelan dan komunikasi mengenai sebuah sistem dengan menggunakan diagram teks-teks pendukung. UML hanya berfungsi untuk melakukan pemodelan. Jadi pengguna UML tidak terbatas pada metodologi tertentu, meskipun pada kenyataanya UML paling banyak digunakan metodologi objek orientasi (Rosa A.S \& M.Shalahuddin, 2019).

a. Analisis Sistem

Analisis sistem adalah penguraian dari suatu informasi yang 


\section{, \\ HORIZON}

PENDIDIKAN
JURNAL HORIZON PENDIDIKAN

Publish by: Library of STKIP PGRI Sumatera Barat

E-ISSN : 2775-5770

Vol. 1 No. 4 (November 2021) (676-687)

http://ejournal.stkip-pgri-sumbar.ac.id/index.php/horizon

utuh ke dalam bagian-bagian case diagram menggambarkan komponennya dengan maksud untuk mengidentifikasi dan mengevaluasi permasalahan, yang terjadi dan kebutuhan yang diharapkan, sehingga dapat diusulkan perbaikannya.

b. Perancangan Sistem

Perancangan sistem merupakan penggambaran, perencanaan dan pembuatan sketsa atau pengaturan dari beberapa elemen yang terpisah kedalam satu kesatuan yang utuh dan berfungsi.

Tujuan dari perancangan sistem ini adalah untuk memberikan gambaran kepada user dan manajemen tentang sistem baru yang akan diusulkan memberi ilustrasi serta rekayasa yang lengkap pada programmer dan ahli teknisi lain yang akan mengimplementasikan sistem. Adapun alat bantu perancangan sebagai berikut:

c. Use Case diagram

Use case menggambarkan
bagaimana seseorang akan
menggunakan sistem, sedangkan
aktor adalah seseorang atau sesuatu
yang berinteraksi dengan sistem. Use

bagaimana proses yang dilakukan oleh aktor terhadap sebuah sistem. Adapun use case diagram sitem informasi penjualan motor bekas dapat digambarkan seperti gambar 3.

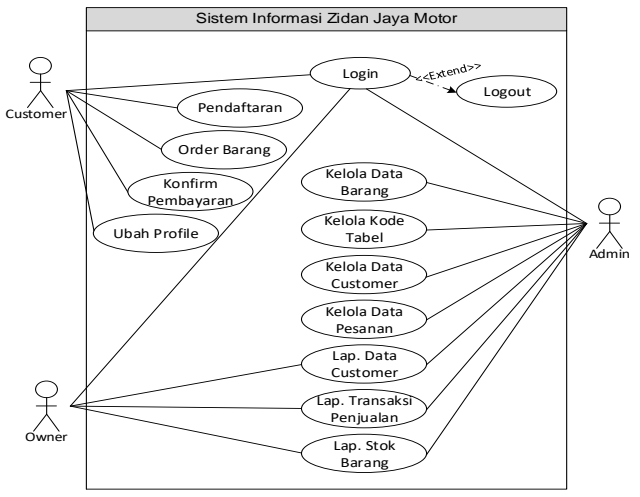

Gambar 3. Use Case Diagram

Admin yaitu karyawan perusahaan yang memiliki tugas atau jobdesk untuk menjalankan tata kelola administrasi perusahaan. Langkah pertama user/admin mengakses halaman aplikasi website, kemudian admin akan disuguhkan ke menu login. Proses masuk ke halaman admin nantinya sistem secara otomatis akan meminta username dan password sebagai hak akses untuk mengoperasikan halaman admin. Setelah proses masuk berhasil, maka admin akan melakukan pengoperasian untuk mengelola data barang, kelola 


\section{JURNAL \\ HORIZON}

PENDIDIKAN

JURNAL HORIZON PENDIDIKAN

Publish by: Library of STKIP PGRI Sumatera Barat

E-ISSN : 2775-5770

Vol. 1 No. 4 (November 2021) (676-687)

http://ejournal.stkip-pgri-sumbar.ac.id/index.php/horizon

data kode, kelola data customer, kelola data pemesanan dan membuat laporan penjualan, laporan data customer, laporan transaksi penjualan, laporan stok barang yang akan di akses untuk pemilik usaha.

Customer atau pelanggan, langkah pertama untuk melakukan pemesanan barang secara online, customer dapat mengakses website Zidan Jaya Motor dengan memasukkan nama e-mail dan password di tampilan form login yang telah disediakan, langkah ini nantinya akan membantu pembeli untuk melihat motor bekas yang tersedia lengkap dengan harga dan spesifikasinya. Dalam melakukan pemesanan, pembeli diharuskan untuk memasukkan biodata/data diri dengan benar di tampilan form menu yang disediakan. Setelah tahapan diatas selesai, pembeli tinggal menunggu konfirmasi melalui via e-mail dari Zidan Jaya Motor yang dikirim ke alamat e-mail customer.

Owner atau pimpinan adalah orang yang menjalankan dealer Zidan Jaya Motor. owner mempunyai peranan yang sangat penting dalam menyediakan dana untuk membiayai kebutuhan pada suatu perusahaan atau bisnis. Dalam perancangan sistem informasi Zidan Jaya Motor, pemilik usaha dapat melakukan pengecekan laporan keluar-masuk barang serta laporan data customer, laporan transaksi penjualan dan laporan stok barang, sehingga pemilik usaha dapat memantau perkembangan penjualan yang terjadi pada website Zidan Jaya Motor.

\section{d. Activity Diagram}

Aktivitas diagram adalah bentuk visual aliran kerja yang berisikan aktivitas atau tindakan pemilihan, pengulangan, dan concurrency. Aktifiti diagram mempunyai komponen dengan bentuk tertentu, berupa simbol tanda panah yang menghubungkan urutan aktivitas dari awal sampai akhir.

\section{e. Activity Diagram Pendaftaran Customer}

Aktivitas diagram pendaftaran merupakan pengguna atau customer membuka website kemudian pilih menu pendaftaran dan mengisi form pendaftaran. 


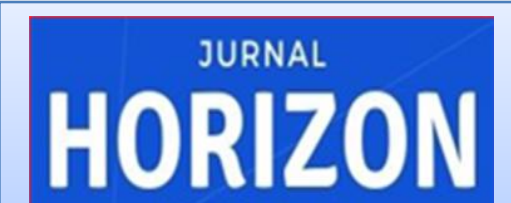

PENDIDIKAN
JURNAL HORIZON PENDIDIKAN

Publish by: Library of STKIP PGRI Sumatera Barat

E-ISSN : 2775-5770

Vol. 1 No. 4 (November 2021) (676-687)

http://ejournal.stkip-pgri-sumbar.ac.id/index.php/horizon

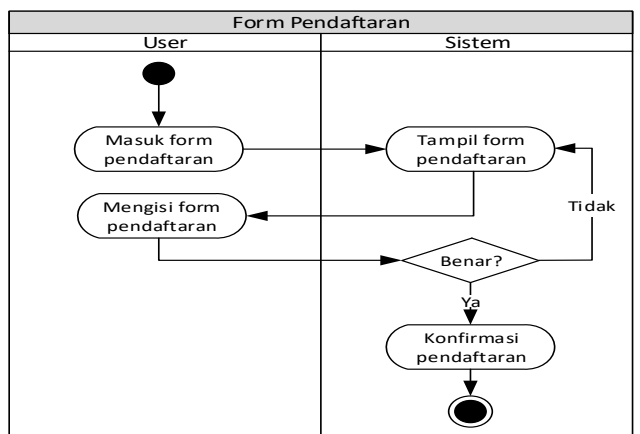

Gambar 4. Activity Diagram Pendaftaran

\section{f. Activity Diagram Login}

Menggambarkan aktivitas yang dapat dikerjakan pada sistem, suatu aktivitas dapat direalisasikan oleh satu use case atau lebih.

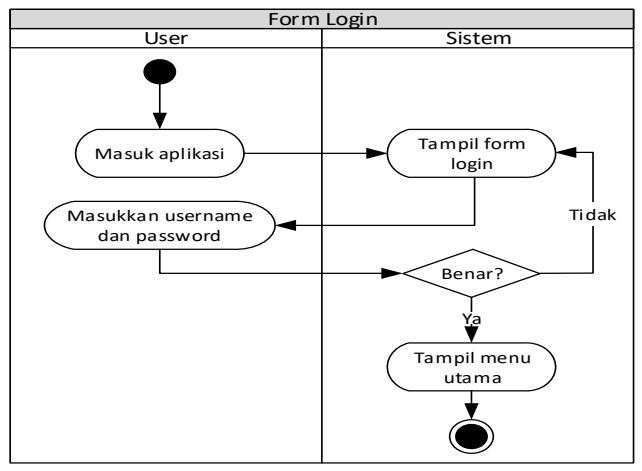

Gambar 5. Activity diagram login

\section{g. Sequence Diagram}

Sequence diagram digunakan untuk menggambarkan perilaku aktor pada sebuah sistem secara detail menurut waktu. Diagram ini menunjukkan sejumlah contoh objek dan message (pesan) yang diletakkan diantara objek-objek di dalam use case. h. Sequence Diagram Pendaftaran

Aktor user melakukan interaksi langsung di interface dan mengisi form pendaftaran, kemudian mengirim keseluruhan data ke database. Apabila pendaftaran berhasil maka aktor akan memiliki notifikasi bahwasanya pengisian form pendaftaran sukses dilakukan.

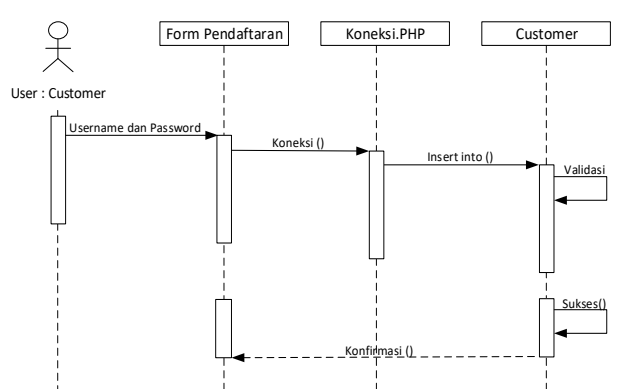

Gambar 6. Sequence Diagram Pendaftaran

\section{i. Sequence Diagram Login}

Aktor user dapat login di interface dan memasukkan username dan password. Kemudian dilakukan proses validasi data jika sudah selesai dengan identitasnya maka aktor dapat masuk ke dalam sistem penjualan.

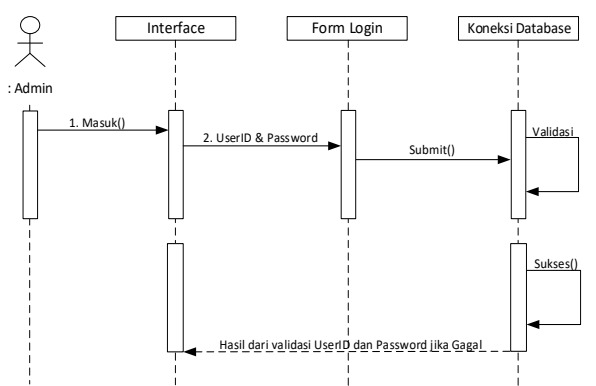

Gambar 7. Sequence Diagram Login 


\section{JURNAL \\ HORIZON}

PENDIDIKAN

JURNAL HORIZON PENDIDIKAN

Publish by: Library of STKIP PGRI Sumatera Barat

E-ISSN : 2775-5770

Vol. 1 No. 4 (November 2021) (676-687)

http://ejournal.stkip-pgri-sumbar.ac.id/index.php/horizon

\section{j. Class Diagram}

Class diagram adalah sebuah spesifikasi yang jika diinstansiasi akan menghasilkan sebuah objek dan merupakan inti dari pengembangan dan desain berorientasi objek. Diagram ini menjelaskan bagaimana hubungan antara class pada sistem informasi tersebut terjadi. Untuk lebih jelasnya class diagram sistem informasi penjualan motor bekas dapat digambarkan seperti gambar.

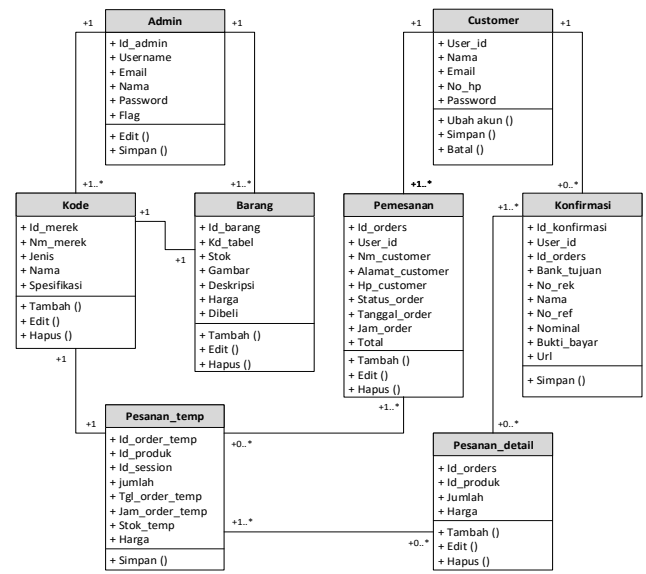

Gambar 8. Class Daigram

\section{k. Blackbox Testing}

Pengujian blackbox merupakan pengujian program berdasarkan fungsi dari program. Tujuan dari metode blackbox ini adalah untuk menemukan kesalahan fungsi pada program (Aini \& Nurgiyatna, 2020).
Tabel 1. Pengujian login

\begin{tabular}{llll}
\hline Deskripsi & Pengujian & Output & Hasil \\
\hline Pengujian & Username & Berhasil & Valid \\
Login & & masuk & \\
& & ke \\
& Password & $\begin{array}{l}\text { menu } \\
\text { utama }\end{array}$ & \\
& & & \\
\hline
\end{tabular}

Tabel 2. Pengujian Input Data File

\begin{tabular}{llll}
\hline Deskripsi & Pengujian & Output & Hasil \\
\hline Input & Membuka & Muncul & Valid \\
File & $\begin{array}{l}\text { menu } \\
\text { data file }\end{array}$ & daftar & \\
& file & \\
& $\begin{array}{l}\text { Input data } \\
\text { file }\end{array}$ & $\begin{array}{l}\text { Penamba } \\
\text { han data }\end{array}$ & Valid \\
& & $\begin{array}{l}\text { file } \\
\text { behasil } \\
\text { disimpan }\end{array}$ & \\
& & pembaha & Valid \\
& & Mengedit \\
data file & ruan & \\
& & data file & \\
& & \\
& Mengha & Data file & Valid \\
pus data & berhasil & \\
file & dihapus & \\
\hline & & & \\
& & &
\end{tabular}

Tabel 3. Pengujian Input Data Barang

\begin{tabular}{|c|c|c|c|}
\hline Deskripsi & Pengujian & Output & Hasil \\
\hline \multirow[t]{4}{*}{$\begin{array}{l}\text { Input } \\
\text { Data } \\
\text { Barang }\end{array}$} & $\begin{array}{l}\text { Membuka } \\
\text { menu } \\
\text { data } \\
\text { barang }\end{array}$ & $\begin{array}{l}\text { Muncul } \\
\text { daftar } \\
\text { barang }\end{array}$ & Valid \\
\hline & $\begin{array}{l}\text { Input data } \\
\text { barang }\end{array}$ & $\begin{array}{l}\text { Data } \\
\text { barang } \\
\text { disimpan }\end{array}$ & Valid \\
\hline & $\begin{array}{l}\text { Edit data } \\
\text { barang }\end{array}$ & $\begin{array}{l}\text { pembah } \\
\text { aruan } \\
\text { data } \\
\text { barang }\end{array}$ & Valid \\
\hline & $\begin{array}{l}\text { Hapus } \\
\text { data } \\
\text { barang }\end{array}$ & $\begin{array}{l}\text { Data } \\
\text { barang } \\
\text { berhasil } \\
\text { dihapus }\end{array}$ & Valid \\
\hline
\end{tabular}




\section{granc \\ HORIZON}

PENDIDIKAN
JURNAL HORIZON PENDIDIKAN

Publish by: Library of STKIP PGRI Sumatera Barat

E-ISSN : 2775-5770

Vol. 1 No. 4 (November 2021) (676-687)

http://ejournal.stkip-pgri-sumbar.ac.id/index.php/horizon

Tabel 4. Pengujian Input data Pemesanan

\begin{tabular}{|c|c|c|c|}
\hline $\begin{array}{l}\text { Deskrips } \\
\mathrm{i}\end{array}$ & $\begin{array}{l}\text { Pengujia } \\
\mathrm{n}\end{array}$ & Output & $\begin{array}{l}\text { Has } \\
\text { il }\end{array}$ \\
\hline \multirow[t]{3}{*}{$\begin{array}{l}\text { Input } \\
\text { data } \\
\text { pemesan } \\
\text { an }\end{array}$} & $\begin{array}{l}\text { Klik } \\
\text { keranjan } \\
\text { g belanja }\end{array}$ & $\begin{array}{l}\text { Muncul } \\
\text { daftar } \\
\text { keranjang } \\
\text { belanja }\end{array}$ & $\begin{array}{c}\text { Vali } \\
d\end{array}$ \\
\hline & $\begin{array}{l}\text { Tambah } \\
\text { pesanan }\end{array}$ & $\begin{array}{l}\text { Penambaha } \\
\mathrm{n} \text { data } \\
\text { pemesanan } \\
\text { berhasil } \\
\text { disimpan }\end{array}$ & $\begin{array}{c}\text { Vali } \\
d\end{array}$ \\
\hline & $\begin{array}{l}\text { Konfirm } \\
\text { asi data } \\
\text { pemesan } \\
\text { an }\end{array}$ & $\begin{array}{l}\text { Konfirmasi } \\
\text { pememasa } \\
\text { nan } \\
\text { berhasil }\end{array}$ & $\begin{array}{c}\text { Vali } \\
d\end{array}$ \\
\hline
\end{tabular}

Tabel 5. Pengujian Konfirmasi

Pembayaran

\begin{tabular}{|c|c|c|c|}
\hline Deskripsi & $\begin{array}{l}\text { Pengujia } \\
\mathrm{n}\end{array}$ & Output & $\begin{array}{c}\text { Has } \\
\text { il }\end{array}$ \\
\hline \multirow[t]{3}{*}{$\begin{array}{l}\text { Konfirm } \\
\text { pembay } \\
\text { aran }\end{array}$} & $\begin{array}{l}\text { Klik } \\
\text { menu } \\
\text { konfirma } \\
\text { si }\end{array}$ & $\begin{array}{l}\text { Muncul } \\
\text { daftar } \\
\text { konfirma } \\
\text { si }\end{array}$ & $\begin{array}{c}\text { Vali } \\
d\end{array}$ \\
\hline & $\begin{array}{l}\text { Menamb } \\
\text { ah input } \\
\text { data } \\
\text { konfirma } \\
\text { si }\end{array}$ & $\begin{array}{l}\text { Penamba } \\
\text { han data } \\
\text { konfirma } \\
\text { si } \\
\text { berhasil } \\
\text { disimpan }\end{array}$ & $\begin{array}{c}\text { Vali } \\
d\end{array}$ \\
\hline & $\begin{array}{l}\text { Konfirm } \\
\text { asi data } \\
\text { pembaya } \\
\text { ran }\end{array}$ & $\begin{array}{l}\text { Berhasil } \\
\text { disimpan }\end{array}$ & $\begin{array}{c}\text { Vali } \\
d\end{array}$ \\
\hline
\end{tabular}

Tabel 6. Pengujian Cetak Lap.

penjualan

\begin{tabular}{|c|c|c|}
\hline $\begin{array}{l}\text { Deskrip } \\
\text { si }\end{array}$ & Pengujian & Output \\
\hline
\end{tabular}

\begin{tabular}{|c|c|c|c|}
\hline $\begin{array}{l}\text { Cetak } \\
\text { lapora } \\
\mathrm{n} \\
\text { penjua } \\
\text { lan }\end{array}$ & $\begin{array}{l}\text { Klik menu } \\
\text { laporan } \\
\text { penjualan }\end{array}$ & $\begin{array}{l}\text { Muncul } \\
\text { daftar } \\
\text { laporan } \\
\text { penjual } \\
\text { an }\end{array}$ & $\begin{array}{l}\text { Val } \\
\text { id }\end{array}$ \\
\hline & $\begin{array}{l}\text { Masukkan } \\
\text { range } \\
\text { tanggal/bula } \\
\text { n/tahun } \\
\text { sesuai } \\
\text { laporan yang } \\
\text { ingin } \\
\text { ditampilkan }\end{array}$ & $\begin{array}{l}\text { Muncul } \\
\text { laoran } \\
\text { penjual } \\
\text { an }\end{array}$ & $\begin{array}{l}\text { Val } \\
\text { id }\end{array}$ \\
\hline Tabel 7. & engujian cetak 1 & ap. Baran & \\
\hline $\begin{array}{l}\text { Deskrip } \\
\text { si }\end{array}$ & Pengujian & Output & $\begin{array}{c}\text { Has } \\
\text { il }\end{array}$ \\
\hline $\begin{array}{l}\text { Cetak } \\
\text { lapora } \\
\mathrm{n} \\
\text { baran }\end{array}$ & $\begin{array}{l}\text { Klik menu } \\
\text { laporan } \\
\text { barang }\end{array}$ & $\begin{array}{l}\text { Muncul } \\
\text { daftar } \\
\text { laporan } \\
\text { barang }\end{array}$ & $\begin{array}{l}\text { Val } \\
\text { id }\end{array}$ \\
\hline $\mathrm{g}$ & $\begin{array}{l}\text { Masukkan } \\
\text { range } \\
\text { tanggal/bula } \\
\text { n/tahun } \\
\text { sesuai } \\
\text { laporan yang } \\
\text { ingin } \\
\text { ditampilkan }\end{array}$ & $\begin{array}{l}\text { Muncul } \\
\text { laporan } \\
\text { penjual } \\
\text { an }\end{array}$ & $\begin{array}{l}\text { Val } \\
\text { id }\end{array}$ \\
\hline Tabel & $\begin{array}{l}\text { Pengujian cet } \\
\text { Customer }\end{array}$ & ap. & \\
\hline $\begin{array}{l}\text { Deskrip } \\
\text { si }\end{array}$ & Pengujian & Output & $\begin{array}{l}\text { Has } \\
\text { il }\end{array}$ \\
\hline $\begin{array}{l}\text { Cetak } \\
\text { daftar } \\
\text { custo } \\
\text { mer }\end{array}$ & $\begin{array}{l}\text { Klik menu } \\
\text { laporan } \\
\text { customer }\end{array}$ & $\begin{array}{l}\text { Muncul } \\
\text { form } \\
\text { laporan } \\
\text { cutomer }\end{array}$ & $\begin{array}{l}\text { Val } \\
\text { id }\end{array}$ \\
\hline
\end{tabular}

HASIL DAN PEMBAHASAN

Hasil dan pembahasan dari sistem informasi praktek kerja 


\section{inant \\ HORIZON}

PENDIDIKAN

JURNAL HORIZON PENDIDIKAN

Publish by: Library of STKIP PGRI Sumatera Barat

E-ISSN : 2775-5770

Vol. 1 No. 4 (November 2021) (676-687)

http://ejournal.stkip-pgri-sumbar.ac.id/index.php/horizon

industri berbasis web dapat dijelaskan sebagai berikut:

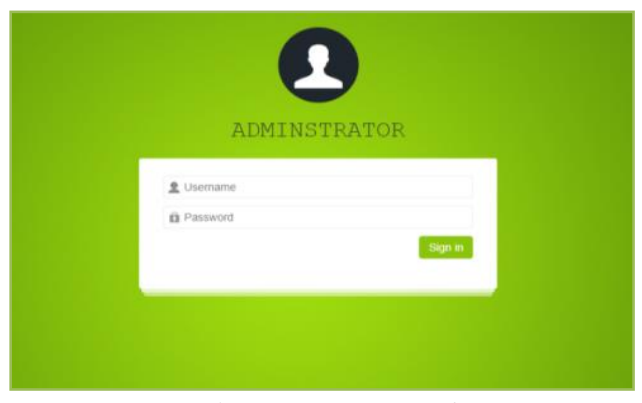

Gambar 9. Login Admin

Halaman diatas merupakan halaman login bagi admin yang dikhususkan untuk mengelola aplikasi penjualan berbasis website ini.

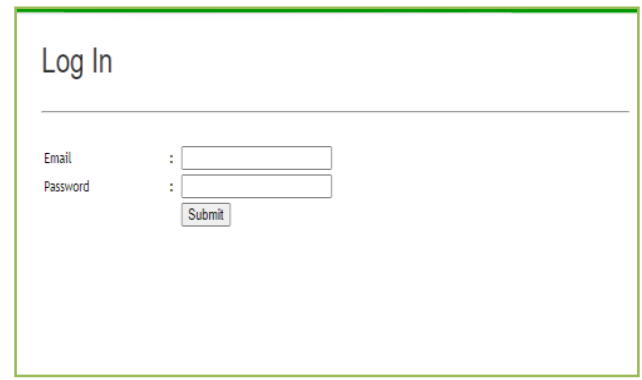

Gambar 10. Login Customer

Halaman diatas merupakan halaman login bagi user/pelanggan yang ingin melakukan pemesanan ataupun melihat kebutuhan yang diperlukannya.

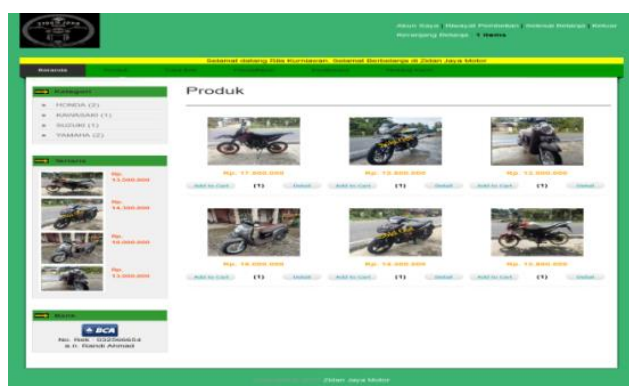

Gambar 11. Tampilan Menu Utama
Halaman utama menjelaskan tampilan depan dari web Zidan Jaya Motor yang berisi menu-menu dari aplikasi web tersebut. Berikut adalah tampilan Halaman utama web Zidan Jaya Motor.

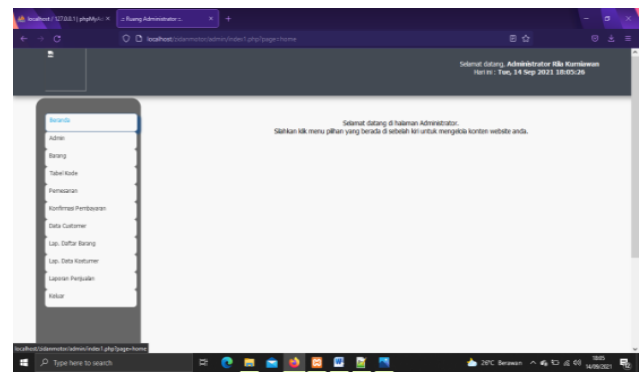

Gambar 12. Halaman Beranda Admin

Halaman beranda admin terdiri dari menu-menu sistem informasi yaitu pengentrian data, proses dan laporan serta kita juga dapat melihat siapa saja user yang bisa mengakses sistem informasi tersebut.

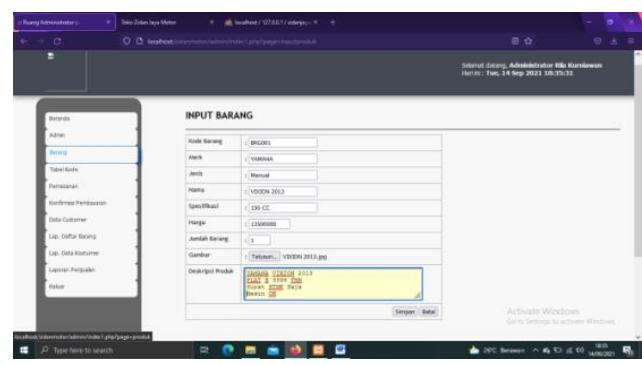

Gambar 13. Tampilan Form Input Data Barang

Pada form input data barang terdiri dari id file, nama barang, harga, berat, stok, upload gambar, dan deskripsi. setelah kolom-kolom form input data barang diisi, tekan tombol 


\section{inant \\ HORIZON}

PENDIDIKAN
JURNAL HORIZON PENDIDIKAN

Publish by: Library of STKIP PGRI Sumatera Barat

E-ISSN : 2775-5770

Vol. 1 No. 4 (November 2021) (676-687)

http://ejournal.stkip-pgri-sumbar.ac.id/index.php/horizon

simpan untuk menyimpan data barang ke database, juga terdapat tombol edit untuk untuk mengubah data, detail melihat detail barang dan hapus untuk menghapus data barang.

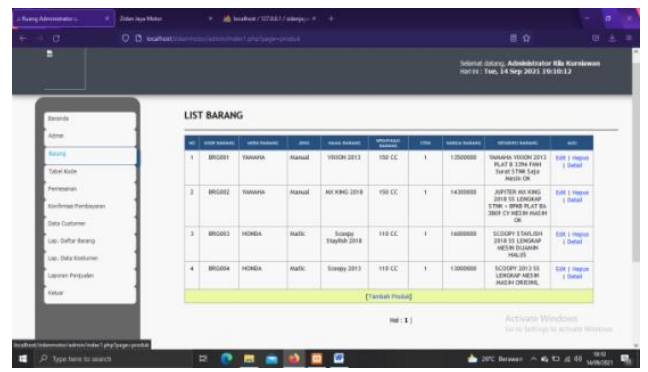

Gambar 14. Tampilan List Data Barang

Setelah penginputan data barang, kemudian dilanjutkan dengan proses "simpan" maka sistem secara otomatis akan menampilkan halaman list data barang seperti gambar diatas.

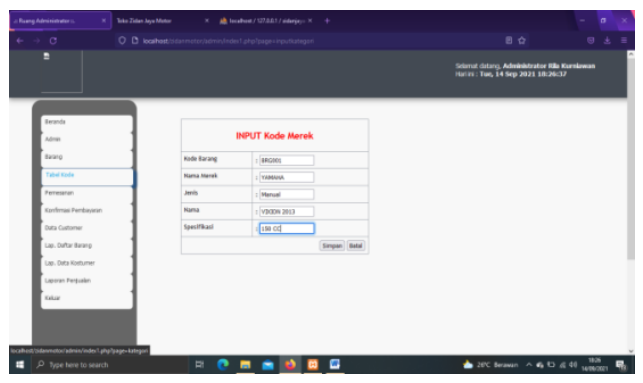

Gambar 15. Input Data Kode

Form input data kode diatas terdiri dari tahapan yang akan diisikan. Setalah form input kode diisi, tekan menu simpan untuk menyimpan ke database.

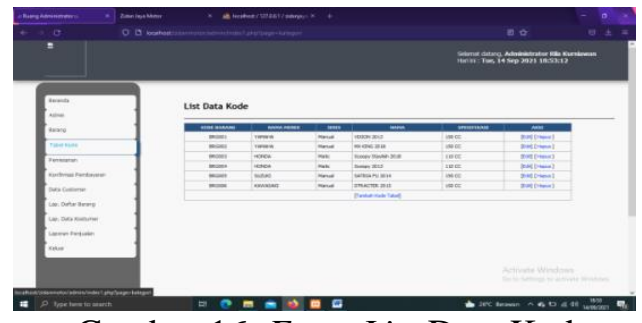

Gambar 16. Form List Data Kode

Setelah penginputan data kode berhasil disimpan, maka sistem secara otomatis akan menampilkan halaman list data kode seperti gambar diatas.

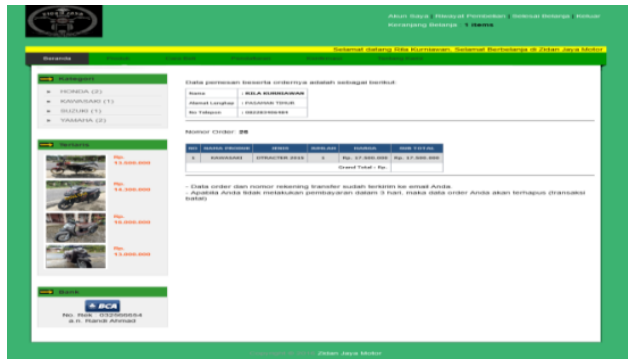

Gambar 17. Tampilan Form Input Pemesanan Oleh Customer

Pada form input data pemesanan terdiri nama penerima,alamat pengiriman, no hp, ongkos kirim. setelah kolom-kolom form input data pemesanan diisi kemudian tekan tombol konfirmasi agar data dapat disimpan kedalam database.

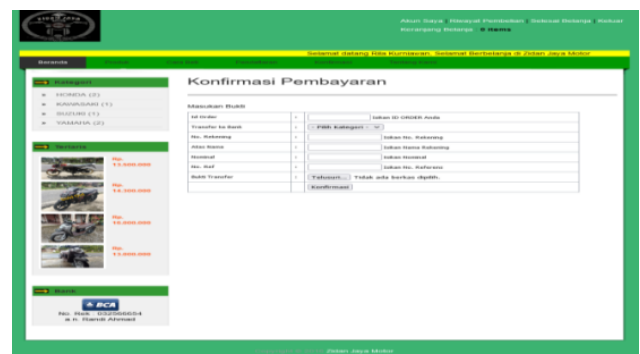

Gambar 18. Konfirmasi Pembayaran Customer 


\section{Inant \\ HORIZON}

PENDIDIKAN

JURNAL HORIZON PENDIDIKAN

Publish by: Library of STKIP PGRI Sumatera Barat

E-ISSN : 2775-5770

Vol. 1 No. 4 (November 2021) (676-687)

http://ejournal.stkip-pgri-sumbar.ac.id/index.php/horizon

Pada form input data konfirmasi pembayaran terdiri id order, bank, no rekening, nama, nominal dan no referensi. setelah kolom-kolom form input data konfirmasi pembayaran diisi, tekan tombol konfirmasi untuk proses simpan ke database.

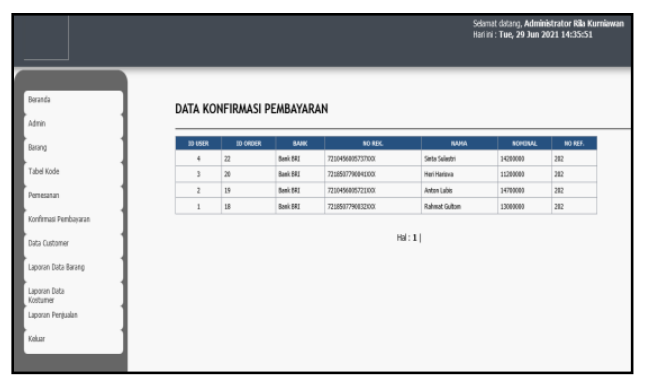

Gambar 19. List Data Konfirmasi Pembayaran

Tampilan diatas merupakan halaman list konfirmasi pembayaran pada menu admin.

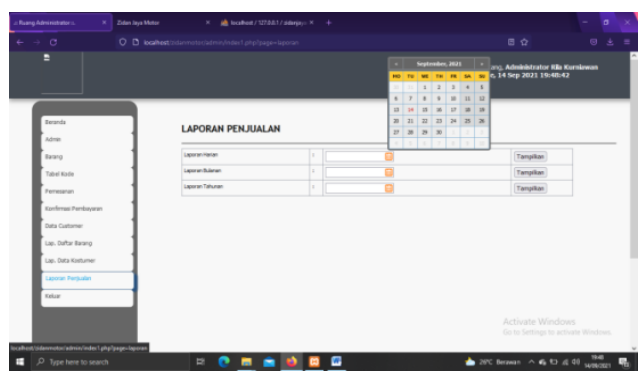

Gambar 20. Laporan Penjualan

Pada laporan penjualan terdapat semua data penjualan perharinya pada Zidan Jaya Motor, pilih laporan penjualan harian/ bulanan atau tahunan yang akan dicetak, pilih range tanggal/bulan/tahun lalu klik cetak maka akan tampil laporan yang siap untuk di print.

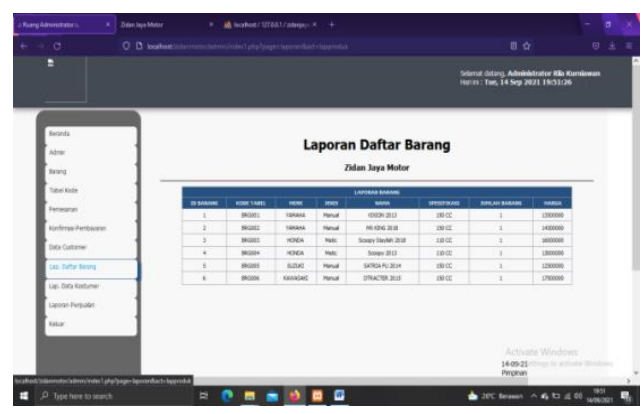

Gambar 24. Laporan Daftar Barang

Pada Laporan daftar barang terdapat semua data barang pada Zidan Jaya Motor, pilih laporan barang harian/ bulanan atau tahunan yang akan dicetak, pilih range tanggal/bulan/tahun lalu menekan tombol cetak maka akan tampil laporan yang siap untuk di print.

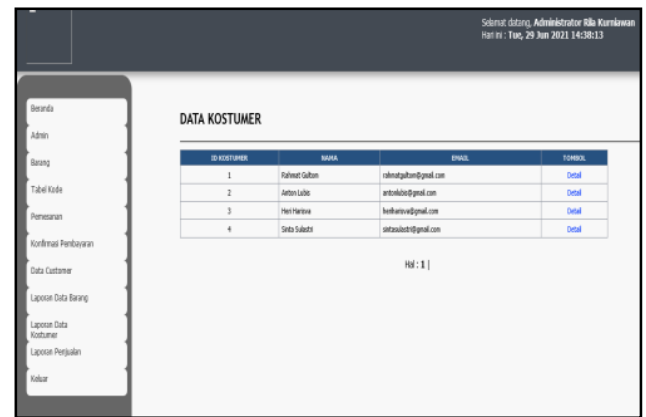

Gambar 25. Laporan Data Customer

Pada Laporan data customer terdapat semua data barang pada Zidan Jaya Motor, pilih laporan customer harian/ bulanan atau tahunan yang akan dicetak, pilih range tanggal/bulan/tahun lalu 


\section{JURNAL \\ HORIZON}

PENDIDIKAN
JURNAL HORIZON PENDIDIKAN

Publish by: Library of STKIP PGRI Sumatera Barat

E-ISSN : 2775-5770

Vol. 1 No. 4 (November 2021) (676-687)

http://ejournal.stkip-pgri-sumbar.ac.id/index.php/horizon

menekan tombol cetak untuk melakukan proses print.

\section{KESIMPULAN}

Perancangan sistem informasi penjualan motor bekas berbasis web pada Zidan Jaya Motor dengan menggunakan metode SDLC yang terdiri dari perencanaan, analisis, perancangan pengujian, implementasi dan pemeliharaan. Perancangan sistem ini menggunakan bahasa pemograman PHP MyAdmin, XAMPP dan menggunakan database MySql sebagai media penyimpanan.

Maka dapat diambil kesimpulan sebagai berikut:

1. Dengan adanya sistem informasi penjualan berbasis website memudahkan pihak Zidan Jaya Motor dalam proses pengelolaan data, seperti stok barang, transaksi penjualan dan laporan penjualan harian, bulanan maupun tahunan.

2. Keuntungan sistem informasi penjualan berbasis website ini dapat memberikan pelayanan yang optimal kepada pelanggan melalui dukungan sistem informasi yang efektif. Pencarian barang dapat dilakukan dengan singkat, maka pelanggan otomatis akan merasa senang dan puas karena lebih hemat waktu.

3. Website memiliki kinerja yang lebih baik dalam menjaga keamanan data, pihak Zidan Jaya Motor dapat menentukan pengguna/administrator khusus yang dapat mengakses data-data tertentu, sehingga orang yang tidak diberikan hak akses tidak dapat membukanya, maka berbagai kesalahan dan gangguan dapat diantisipasi dan diperbaiki dengan segera.

4. Dengan dukungan sumber daya manusia serta sistem informasi yang terarah, perusahaan akan lebih produktif. Apabila volume penjualan meningkat, pendapatan perusahaan otomatis akan semakin besar.

\section{DAFTAR PUSTAKA}

Aini, T. N., \& Nurgiyatna, S. T. (2020). Sistem Informasi Penjualan Sepeda Motor Bekas di Dealer Sinar Maju Motor Purwodadi. 21(01), 1-9. http://eprints.ums.ac.id/id/eprint/86 985 
Publish by: Library of STKIP PGRI Sumatera Barat

E-ISSN : 2775-5770

Vol. 1 No. 4 (November 2021) (676-687)

http://ejournal.stkip-pgri-sumbar.ac.id/index.php/horizon

Iqbal, M. (2019). Perancangan Aplikasi Penjualan Sepeda Motor Dan Sparepart Motor Berbasis Web ( Studi Kasus : UD . Variasi Motor di Matang Gelumpang Dua ). 3(1), 5156.

Iriadi, N., \& Rosdiana, N. (2017). Perancangan Sistem Informasi Penjualan Minuman Kemasan Berbasis Web Pada Toko Bambu Sejahtera Bekasi. Jurnal Khatulistiwa Informatika, V(1), 4247.

Rosa A.S \& M.Shalahuddin. (2019). Rekayasa Perangkat Lunak Terstruktur dan Berorientasi Objek Edisi Revisi (Oktober 19). Informatika Bandung.
Rossa A. S., M. S. (2018). Rekayasa Perangkat Lunak. Informatika.

Triraharjo, B., Nguyen, P. T., Perumal, E., Shankar, K., Abadi, S., Hashim, W., \& Maseleno, A. (2019). Ecommerce application system at motorcycle showroom. International Journal of Engineering and Advanced Technology, 8(6 Special Issue 2), 1022-1025. https://doi.org/10.35940/ijeat.F1310. 0886S219

Yulisda, D., Nurfasha, S., Sistem, P., Fakultas, I., Universitas, T., Unimal, K., \& Indah, B. (2021). Perancangan sistem informasi pengarsipan buku tanah di kantor pertanahan kabupaten bireuen. 5(2), 227-233. 